\title{
Association between Hypertension and Periodontitis: Possible Mechanisms
}

\author{
Xin-Fang Leong, ${ }^{1,2}$ Chun-Yi Ng, ${ }^{1}$ Baharin Badiah, ${ }^{3}$ and Srijit Das ${ }^{4}$ \\ ${ }^{1}$ Department of Pharmacology, Faculty of Medicine, Universiti Kebangsaan Malaysia, Jalan Raja Muda Abdul Aziz, \\ 50300 Kuala Lumpur, Malaysia \\ ${ }^{2}$ Department of Clinical Oral Biology, Faculty of Dentistry, Universiti Kebangsaan Malaysia, Jalan Raja Muda Abdul Aziz, \\ 50300 Kuala Lumpur, Malaysia \\ ${ }^{3}$ Department of Periodontology, Faculty of Dentistry, Universiti Kebangsaan Malaysia, Jalan Raja Muda Abdul Aziz, \\ 50300 Kuala Lumpur, Malaysia \\ ${ }^{4}$ Department of Anatomy, Faculty of Medicine, Universiti Kebangsaan Malaysia, Jalan Raja Muda Abdul Aziz, \\ 50300 Kuala Lumpur, Malaysia
}

Correspondence should be addressed to Srijit Das; drsrijit@gmail.com

Received 9 September 2013; Accepted 15 December 2013; Published 8 January 2014

Academic Editors: K. Nagano and I. Tomas

Copyright (C) 2014 Xin-Fang Leong et al. This is an open access article distributed under the Creative Commons Attribution License, which permits unrestricted use, distribution, and reproduction in any medium, provided the original work is properly cited.

\begin{abstract}
This review is to examine the current literatures on the relationship between periodontitis and hypertension as well as to explore the possible biological pathways underlying the linkage between these health conditions. Hypertension is one of the major risk factors for cardiovascular diseases. Oxidative stress and endothelial dysfunction are among the critical components in the development of hypertension. Inflammation has received much attention recently and may contribute to a pivotal role in hypertension. Periodontitis, a chronic low-grade inflammation of gingival tissue, has been linked to endothelial dysfunction, with blood pressure elevation and increased mortality risk in hypertensive patients. Inflammatory biomarkers are increased in hypertensive patients with periodontitis. Over the years, various researches have been performed to evaluate the involvement of periodontitis in the initiation and progression of hypertension. Many cross-sectional studies documented an association between hypertension and periodontitis. However, more well-designed prospective population trials need to be carried out to ascertain the role of periodontitis in hypertension.
\end{abstract}

\section{Introduction}

The periodontal diseases are a group of chronic inflammatory diseases, involving the soft tissue and bone surrounding the teeth in the jaws, or known as periodontium. Periodontal diseases including gingivitis and periodontitis are among the most common dental diseases after tooth decay in humans. Periodontal diseases are characterized by inflammation of tooth-supporting tissues caused by bacterial infection [1] Gingivitis is a very common reversible condition, which manifests as redness, gum swelling, and bleeding during tooth-brushing and flossing. Gingivitis may progress into periodontitis with further destruction of periodontal tissues ligament and alveolar bone if left without appropriate treatment. Teeth may become mobile and eventually be exfoliated following the diminution of periodontal supporting tissues [2]. This process is attributed to the release of toxic products from the pathogenic bacteria plaque in addition to the inflammation of gingival tissues elicited by the host response [3-6].

Periodontitis is linked to an increased risk of cardiovascular diseases (CVD). The chronic inflammatory process of periodontitis and the host response provide the basis for the hypothetical association between periodontitis and CVD [7, 8]. Hypertension increases the risk of various adverse cardiovascular events such as atherosclerosis, stroke, and coronary heart disease. Oxidative stress and endothelial dysfunction have been hypothesized to be involved in the pathogenesis of hypertension. It is well known that hypertension and 
periodontitis share common risk factors, namely, smoking, stress, increased age, and socioeconomic factors. These risk factors may confound the association between hypertension and periodontitis. Nevertheless, according to the scientific statement issued by the American Heart Association (AHA) published in Circulation, observational studies support an association between periodontal disease and cardiovascular disease, independent of shared risk factors [9].

Although current epidemiological data are yet to provide sufficient evidence to prove a causal relationship between these two diseases, researchers have identified chronic inflammation as an independent link of periodontal disease in the development and progression of CVD in some patients [10]. Both AHA and the American Academy of Periodontology (AAP) were in agreement that more thorough and longterm interventional studies should be carried out in order to gain an in-depth knowledge of the diseases' mechanism. The present review is to examine the existing literature on the association between hypertension and periodontitis. In addition, we looked into the possible mechanisms to explain this link.

\section{Role of Inflammation in Hypertension}

Inflammation is an essential component of immune response to pathogens, damaged cells, and other potent inflammatory stimuli including reactive oxygen radicals. While it provides a pivotal defense mechanism against injurious agents, inflammation itself may cause injury to surrounding healthy bystander cells at the site. Inflammation is therefore a 'doubleedged sword' as this adaptive response might eventually become maladaptive after a chronic time. In blood vessel, inflammation increases vascular permeability and alters cytoskeletal elements in endothelial cells, disrupting the endothelial functions in controlling vascular health. Hence, there is a potential association between vascular inflammation and hypertension.

Over the past three decades, the role of vascular inflammation as a mechanism that participates in the progression of hypertension has gained increasingly strong footing through a tremendous amount of supportive reports [11-13]. Khraibi et al. [14] have found that chronic immunosuppressive therapy with cyclophosphamide significantly attenuated blood pressure (BP) elevation in Okamoto spontaneously hypertensive rats (SHR). This finding supported the hypothesis regarding the involvement of inflammatory reaction in hypertension. In the following year, Norman et al. [15] demonstrated that the development of hypertension was delayed by correcting the immune imbalance state in SHR. Their works continued to show that immunological dysfunction is one of the key aetiologies of hypertension [16]. Dzielak [17] pointed out an inflammatory involvement in hypertension by observing an alteration in the serum immunoglobulin levels in both patients and laboratory animals. Furthermore, the interaction between inflammatory cells and endothelial cells was increased in hypertensive patients [18]. Kampus et al. [19] also found an increase in C-reactive proteins (CRP) and vascular wall stiffness in untreated hypertensive patients. More recently, a link between hypertension and inflammatory responses to oxidized low-density lipoprotein was reported in patients, further suggesting that BP is directly correlated to immunological milieu [20].

The overall contribution of inflammation to vascular damage in hypertensive patients remains an interesting puzzle to be solved by scientists. Research during the last dozen years has shed light on some aspects of this puzzle. Endothelial cells, which line the intimal surface of blood vessel, are the primary target of immunological attack in inflammatory responses. Under normal conditions, the endothelium maintains a vasodilator, antithrombotic, and antiinflammatory state. However, a proinflammatory condition could contribute to endothelial dysfunction.

Certain inflammatory adhesion molecules are involved in the pathogenesis of hypertension and predictive of future cardiovascular events. Vascular cell adhesion molecule-1 (VCAM-1) and intercellular adhesion molecule-1 (ICAM1) are expressed by the endothelial cells. Their expressions are upregulated in response to inflammatory insult [21]. The increased expression of adhesion molecules on endothelial cells is a common process in response to inflammation [22]. VCAM-1 and ICAM-1 are recognized as important cardiovascular risk markers [23, 24]. VCAM-1 and ICAM-1 mediate leukocytes binding to the endothelial lining.

Increased leukocytes infiltration and production of cytokines exaggerate oxidative stress and inflammation, eventually causing a disturbance to the normal endothelial function in regulating BP. Endothelial cells play a crucial part in BP homeostasis through the synthesis of vasodilators such as nitric oxide (NO), prostacyclin $\left(\mathrm{PGI}_{2}\right)$, and endotheliumderived hyperpolarising factor (EDHF) and vasoconstrictors such as endothelin-1, thromboxane $\left(\mathrm{TXA}_{2}\right)$, and angiotensin II. During endothelial dysfunction, the balance between these vasodilators and vasoconstrictors is disturbed in favor of the latter. $\mathrm{Ng}$ et al. [25] have recently shown that the levels of VCAM-1 is directly associated with the imbalance between $\mathrm{PGI}_{2}$ and $\mathrm{TXA}_{2}$ in hypertensive rats. Therefore, inflammation may be involved in hypertension by directly damaging the endothelial BP regulation. Figure 1 depicts the mechanism of elevating BP in linkage to vascular inflammation.

\section{Evidences of Association between Hypertension and Periodontitis}

Hypertension is a major global health disorder affecting about 972 million adult populations in year 2000. This number is expected to grow to 1.56 billion by the year 2025 [26]. Prevalence of hypertension in most developing countries is comparable to the developed countries [27, 28]. Hypertension is defined when a patient has an elevated systolic $\mathrm{BP}$ greater than $140 \mathrm{mmHg}$ and/or diastolic BP greater than $90 \mathrm{mmHg}$ [29]. A patient with systolic BP ranging between $120 \mathrm{mmHg}$ and $139 \mathrm{mmHg}$, and/or diastolic BP of $80 \mathrm{mmHg}$ to $89 \mathrm{mmHg}$, is categorized as prehypertensive. Patients at this stage have the tendency to develop hypertension; hence medical approaches and life style need to be taken care of [29]. 


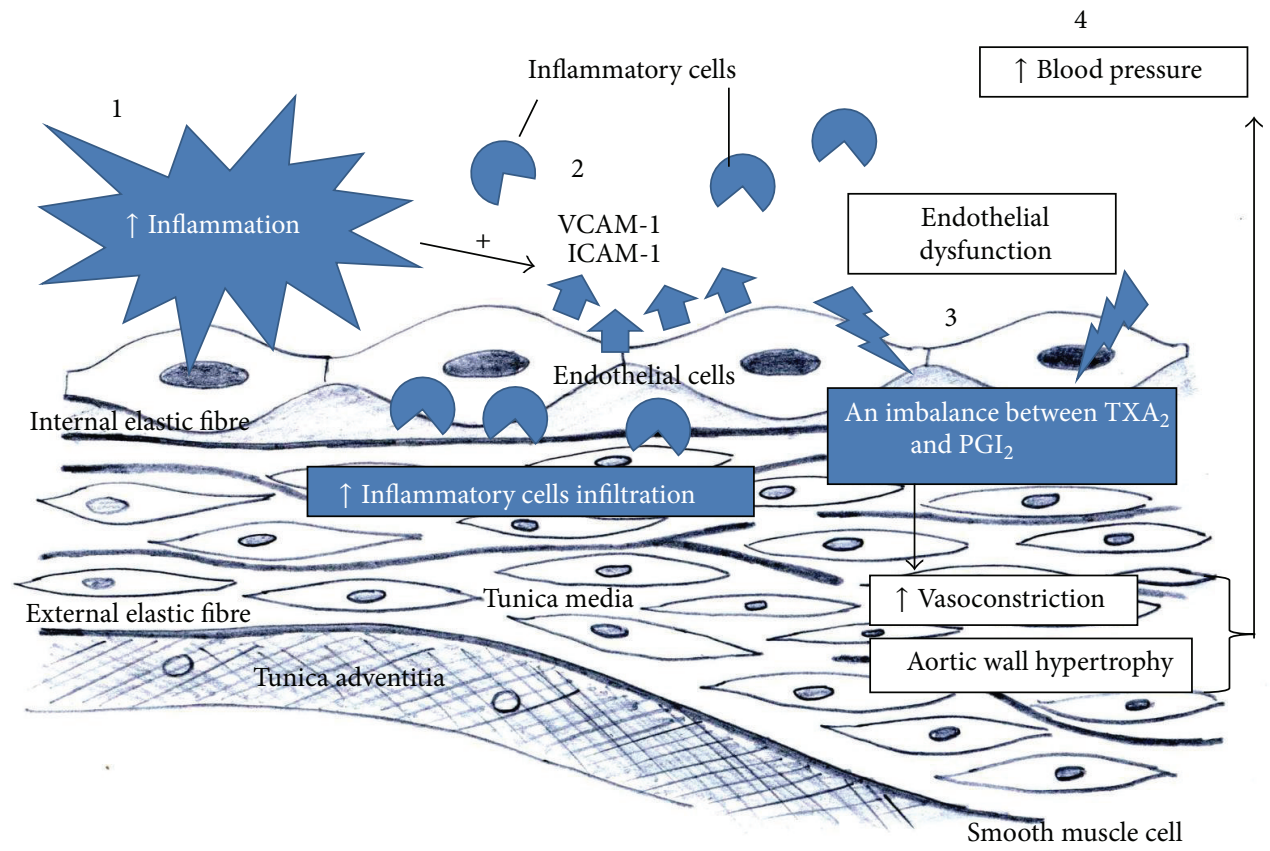

FIGURE 1: (1) Inflammatory stimuli induce the expression of cellular adhesion molecules such as vascular cell adhesion molecule-1 (VCAM-1) and intracellular adhesion molecule-1 (ICAM-1) on endothelial cells. (2) Increased VCAM-1 and ICAM-1 expressions recruit more leukocytes to the site of inflammation. (3) Leukocytes infiltration and production of cytokines lead to oxidative stress and inflammation, which result in endothelial dysfunction, affecting the balance of synthesis between vasodilators and vasoconstrictors. The imbalance favours vasoconstriction and adverse vascular remodelling, (4) consequently leading to elevation of blood pressure.

More than 700 species of bacteria are estimated to be found in the oral cavity [30, 31]. These bacteria form a symbiosis relationship while living at various oral sites [30, 31]. Periodontitis is often associated with extensive formation of dental plaques or better known as biofilms, at the tooth and the gingival interface [32]. The biofilms protect microbes from the host defense system and antimicrobial agents such as antibiotics. The biofilms are mainly dominated by anaerobic, Gram-negative bacteria, for example, Porphyromonas gingivalis ( $P$. gingivalis), Aggregatibacter actinomycetemcomitans, and spirochetes like Treponema denticola [33-35].

Although bacterial biofilms are necessary for the development of periodontal disease, they are not the sole contributor to the disease. Hence, a susceptible host is required. Dental biofilms release a variety of biologically active products, including bacterial lipopolysaccharides, chemotactic peptides, protein toxins, and organic acids [36]. Production and release of proinflammatory prostaglandins and cytokines such as interleukin-1 beta (IL-1 $\beta$ ), interleukin-6 (IL-6), interleukin-8 (IL-8), and tumour necrosis factor-alpha (TNF$\alpha$ ) are triggered in response to stimuli of dental biofilms [37, 38]. The active products by biofilms and host responses are responsible for periodontal tissue destruction. The released products may also affect various disease pathways such as atherosclerosis and mucosal inflammation [36].

Over the past years, studies carried out in patients with periodontal disease have related hypertension with chronic periodontal disease localized in the gingival tissues [39].
These studies documented that hypertensive subjects exhibited a more detrimental periodontal status [40-43]. Epidemiological studies to date have shown an association between hypertension and periodontitis (Table 1). Nevertheless, the related studies were mostly cross-sectional, with varied numbers of subject and assessment methods. For instance, earlier investigations depended on surrogate markers of exposure, including depth of periodontal pocket, attachment loss, and dental indices, or based on the number of missing tooth or self-reported periodontal status such as oral hygiene practice. As a result, data obtained from early studies need to be interpreted with caution, emphasizing the need for further research, as suggested by Tsioufis et al. [44].

\section{Possible Linking Pathways for the Association between Hypertension and Periodontitis}

4.1. Inflammation. Hypertension and periodontitis are two diseases which seem to be profoundly unrelated. However, since periodontitis is a chronic infection that leads to inflammation, the appreciation of periodontitis as a risk factor for hypertension has burgeoned lately. There is now evidence that supports periodontitis as an important risk factor for CVD including stroke [70], peripheral artery disease $[65,71]$, and coronary heart disease [72]. Particularly, the inflammatory response accompanying periodontitis has 
TABLE 1: Studies demonstrating significant association of hypertension and periodontitis.

\begin{tabular}{|c|c|c|c|c|c|c|}
\hline Study & Year & $\begin{array}{l}\text { Country } \\
\text { studied }\end{array}$ & $\begin{array}{l}\text { Sample } \\
\text { size }\end{array}$ & Type of study & Findings & Adjusted for \\
\hline Ogawa et al. [45] & 1998 & Japan & 2000 & Cross-sectional & $\begin{array}{c}\text { Hypertensive subjects had } \\
\text { higher CPITN }\end{array}$ & None \\
\hline Angeli et al. [46] & 2003 & Italy & 104 & Cross-sectional & $\begin{array}{c}\uparrow \mathrm{SBP} \text { with } \uparrow \text { periodontitis } \\
\text { severity }\end{array}$ & None \\
\hline $\begin{array}{l}\text { Taguchi et al. } \\
\text { [47] }\end{array}$ & 2004 & Japan & 98 & Cross-sectional & $\begin{array}{c}\uparrow \mathrm{SBP}(P=0.058), \\
\uparrow \mathrm{DBP}(P=0.021), \\
\text { hypertension in subjects } \\
\text { with missing teeth }(\mathrm{OR}: \\
\text { 3.59; CI: } 1.1-11.7)\end{array}$ & $\begin{array}{l}\text { Obesity, } \\
\text { hypercholesterolemia, } \\
\text { hypertriglyceridemia }\end{array}$ \\
\hline Inoue et al. [48] & 2005 & Japan & 364 & $\begin{array}{l}\text { Cross-sectional ( } 2 \\
\text { time points) }\end{array}$ & $\begin{array}{c}\text { Periodontitis associated } \\
\text { with } \uparrow \mathrm{BP} \text { and WBC count }\end{array}$ & $\begin{array}{c}\text { Age, gender, BMI, smoking, } \\
\text { drinking, hypertension, } \\
\text { DM, WBC count }\end{array}$ \\
\hline $\begin{array}{l}\text { Holmlund et al. } \\
{[42]}\end{array}$ & 2006 & Sweden & 4254 & $\begin{array}{l}\text { Cross-sectional } \\
\text { (Retrospective) }\end{array}$ & $\begin{array}{c}\text { Periodontal pocket related } \\
\text { to hypertension } \\
(P<0.0001), \\
\uparrow \text { periodontitis severity } \\
\text { with hypertension (OR: } \\
\text { 1.32; CI: } 1.13-1.54 ; \\
P<0.0005) \\
\end{array}$ & $\begin{array}{l}\text { Age, gender, number of } \\
\text { teeth, smoking }\end{array}$ \\
\hline $\begin{array}{l}\text { D'Aiuto et al. } \\
\text { [49] }\end{array}$ & 2006 & England & 40 & $\begin{array}{l}\text { Prospective } \\
\text { intervention } \\
\text { randomized } \\
\text { controlled trial }\end{array}$ & $\begin{array}{c}\downarrow 7 \pm 3 \mathrm{mmHg} \text { of SBP after } \\
2 \text { months of intensive } \\
\text { treatment }\end{array}$ & None \\
\hline $\begin{array}{l}\text { Völzke et al. } \\
\text { [50] }\end{array}$ & 2006 & Germany & 4185 & $\begin{array}{l}\text { Cross-sectional } \\
\quad \text { (SHIP) }\end{array}$ & $\begin{array}{c}\uparrow \text { SBP }(P<0.05) \text { and OR: } \\
1.91(\mathrm{CI}: 1.21-3.02 ; P<0.05) \\
\text { for hypertension in male } \\
\text { with } 0-6 \text { teeth compared to } \\
\text { fully dentate }\end{array}$ & $\begin{array}{l}\text { Age, BMI, education, } \\
\text { smoking, diet, DM, } \\
\text { antihypertensive } \\
\text { medication }\end{array}$ \\
\hline $\begin{array}{l}\text { Engström et al. } \\
{[43]}\end{array}$ & 2007 & Sweden & 390 & Cross-sectional & $\begin{array}{l}\text { DBP associated with deep } \\
\text { periodontal pockets }\end{array}$ & $\begin{array}{l}\text { Age, gender, tobacco use, } \\
\text { number of teeth }\end{array}$ \\
\hline Völzke et al. [51] & 2007 & Germany & 1913 & $\begin{array}{l}\text { Cross-sectional } \\
\quad(\text { SHIP })\end{array}$ & $\begin{array}{l}\uparrow \text { SBP (female: } 11.7 \mathrm{~mm} \mathrm{Hg} \\
\text { male: } 5.7 \mathrm{mmHg} \text { ) in } \\
\text { edentulous compared to } \\
\text { fully dentate }\end{array}$ & None \\
\hline $\begin{array}{l}\text { O. A. Ayo-Yusuf } \\
\text { and I. J. } \\
\text { Ayo-Yusuf [52] }\end{array}$ & 2008 & $\begin{array}{l}\text { South } \\
\text { Africa }\end{array}$ & 9098 & $\begin{array}{l}\text { Cross-sectional data } \\
\text { (SADHS) }\end{array}$ & $\begin{array}{l}\text { Higher SBP }(12 \mathrm{mmHg}) \text { and } \\
\text { DBP ( } 5 \mathrm{mmHg} \text { ) in complete } \\
\text { edentulous compared to } \\
\text { fully dentate } \\
\text { OR: } 1.35 \text { (CI: } 1.02-1.78) \text { for } \\
\text { hypertension in complete } \\
\text { edentulous }\end{array}$ & $\begin{array}{l}\text { Age, BMI, DM, education, } \\
\text { income, diet, alcohol, } \\
\text { smoking, family history of } \\
\text { hypertension, oral hygiene } \\
\text { behaviour (daily brushing, } \\
\text { dental visits) }\end{array}$ \\
\hline Franek et al. [53] & 2009 & Poland & 99 & Cross-sectional & $\begin{array}{c}\text { Periodontitis severity } \\
\text { associated with central BP } \\
\text { and pulse pressure } \\
(P<0.05)\end{array}$ & $\begin{array}{c}\text { Age, gender, BMI, } \\
\text { hypertension duration, } \\
\text { smoking, number of drugs } \\
\text { taken }\end{array}$ \\
\hline Fujita et al. [54] & 2009 & Japan & 54551 & Cross-sectional data & $\begin{array}{c}\text { Female (OR: } 1.52 ; \mathrm{CI} \text { : } \\
\text { 1.14-2.03; } P=0.005) ; \text { male } \\
\text { (OR: } 1.24 \text {; CI: } 1.06-1.45 ; \\
P=0.006) \text { for hypertension } \\
\text { in no brushing compared to } \\
\text { brushing after every meal }\end{array}$ & $\begin{array}{l}\text { Age, BMI, smoking, } \\
\text { alcohol, walking time }\end{array}$ \\
\hline
\end{tabular}


TABLE 1: Continued.

\begin{tabular}{|c|c|c|c|c|c|c|}
\hline Study & Year & $\begin{array}{l}\text { Country } \\
\text { studied }\end{array}$ & $\begin{array}{l}\text { Sample } \\
\text { size }\end{array}$ & Type of study & Findings & Adjusted for \\
\hline Nesse et al. [55] & 2010 & $\begin{array}{l}\text { The } \\
\text { Netherlands }\end{array}$ & 1208 & Cross-sectional & $\begin{array}{l}\uparrow \text { hypertension prevalence } \\
\text { in periodontitis subjects } \\
\text { compared to controls } \\
(P=0.001)\end{array}$ & None \\
\hline $\begin{array}{l}\text { de Oliveira et al. } \\
{[56]}\end{array}$ & 2010 & Scotland & 11869 & $\begin{array}{l}\text { Cross-sectional } \\
\text { (Scottish Health } \\
\text { Survey) } \\
\end{array}$ & $\begin{array}{c}\uparrow \text { hypertension prevalence } \\
\text { in subject with rare teeth } \\
\text { brushing }(P<0.001)\end{array}$ & None \\
\hline Morita et al. [57] & 2010 & Japan & 1023 & Prospective cohort & $\begin{array}{c}\text { Periodontal pocket } \\
\text { associated with } \\
\text { hypertension (OR: } 1.5 ; \mathrm{CI} \text { : } \\
1.0-2.3)\end{array}$ & $\begin{array}{l}\text { Age, gender, smoking, } \\
\text { regular exercise, eating } \\
\text { between meals, healthy } \\
\text { body weight }\end{array}$ \\
\hline Franek et al. [58] & 2010 & Poland & 155 & Cross-sectional & $\begin{array}{c}\text { Periodontitis severity } \\
\text { associated with central SBP } \\
(P=0.011) \& \text { DBP } \\
(P=0.006)\end{array}$ & $\begin{array}{l}\text { Age, gender, BMI, } \\
\text { hypertension and insulin } \\
\text { treatment }\end{array}$ \\
\hline Tsakos et al. [59] & 2010 & $\begin{array}{l}\text { United } \\
\text { States of } \\
\text { America }\end{array}$ & 11948 & $\begin{array}{l}\text { Cross-sectional data } \\
\text { (NHANES III) }\end{array}$ & $\begin{array}{c}\uparrow \mathrm{SBP}(P<0.001) \\
\text { OR: } 1.1(\mathrm{CI}: 1-1.1 ; P<0.05) \\
\text { for hypertension in } \uparrow 10 \% \\
\quad \text { gingival bleeding }\end{array}$ & $\begin{array}{l}\text { Age, gender, } \mathrm{BMI} \text {, ethnicity, } \\
\mathrm{CRP}, \text { creatinine, } \mathrm{Na}^{+} / \mathrm{K}^{+} \\
\text {ratio, chronic conditions, } \\
\text { smoking, alcohol, } \\
\text { education, income }\end{array}$ \\
\hline $\begin{array}{l}\text { Desvarieux et al. } \\
{[60]}\end{array}$ & 2010 & $\begin{array}{l}\text { United } \\
\text { States of } \\
\text { America }\end{array}$ & 653 & $\begin{array}{l}\text { Cross-sectional data } \\
\text { (INVEST) }\end{array}$ & $\begin{array}{c}\uparrow \text { SBP \& DBP } \\
\text { OR: } 3.13 \text { (CI: } 1.62-6.03 ; \\
P<0.001 \text { ) for hypertension } \\
\text { when etiological bacterial } \\
\text { burden is high }\end{array}$ & $\begin{array}{l}\text { Age, gender, BMI, race, } \\
\text { education, smoking, DM, } \\
\text { LDL-C, HDL-C, } \\
\text { nonetiological periodontal } \\
\text { bacteria }\end{array}$ \\
\hline Zhang et al. [61] & 2011 & $\begin{array}{l}\text { Xinjang } \\
\text { Uygur }\end{array}$ & 1415 & Cohort & $\begin{array}{l}\text { Periodontitis associated } \\
\text { with hypertension (OR: } \\
\text { 1.75; CI: } 1.30-2.36 ; \\
\qquad P<0.01)\end{array}$ & $\begin{array}{l}\text { Age, gender, BMI, waist } \\
\text { circumference, } \\
\text { glycometabolism disorder, } \\
\text { hyperlipidemia, chronic } \\
\text { kidney disease }\end{array}$ \\
\hline Vidal et al. [62] & 2011 & Brazil & 137 & Case-control & $\begin{array}{c}\text { Hypertension associated } \\
\text { with severe chronic } \\
\text { periodontitis (OR: } 4.04 \text {; CI: } \\
\text { 1.92-8.49), with generalized } \\
\text { chronic periodontitis (OR: } \\
\text { 2.18; CI: } 1.04-4.56)\end{array}$ & $\begin{array}{l}\text { Gender, race, DM, alcohol, } \\
\text { smoking }\end{array}$ \\
\hline Peres et al. [63] & 2012 & Brazil & 1720 & Cross-sectional & $\begin{array}{l}\text { Edentulous subjects had a } \\
\text { SBP } 8.3 \text { mmHg (CI: } \\
0.1-16.7) \text { higher than those } \\
\text { with } 10 \text { or more teeth in } \\
\text { both dental arches }\end{array}$ & $\begin{array}{c}\text { Age, gender, BMI, } \\
\text { education, income, } \\
\text { smoking, alcohol, DM, } \\
\text { leisure physical activity, use } \\
\text { of dental prosthesis, } \\
\text { self-rated health status }\end{array}$ \\
\hline $\begin{array}{l}\text { Rivas- } \\
\text { Tumanyan et al. } \\
{[64]}\end{array}$ & 2013 & Puerto Rica & 182 & Cross-sectional & $\begin{array}{c}\text { Periodontitis severity } \\
\text { associated with high BP } \\
\text { (OR: } 2.93 \text {; CI: } 1.25-6.84) \\
\text { OR: } 4.20 \text { (CI: } 1.28-13.80 \text { ) } \\
\text { restricted to those with } \\
\text { hypertension history } \\
\text { and/or taking } \\
\text { antihypertensive } \\
\text { medications }\end{array}$ & $\begin{array}{l}\text { Age, gender, smoking, } \\
\text { drinking }\end{array}$ \\
\hline
\end{tabular}

Symbols indicate: $\uparrow:$ increased; $\downarrow$ : decreased.

BMI: body mass index; CI: confidence interval; CPITN: community periodontal index of treatment needs; CRP: C-reactive protein; DBP: diastolic blood pressure; DM: diabetes mellitus; HDL-C: high-density lipoprotein cholesterol; INVEST: Oral Infections and Vascular Disease Epidemiology Study; LDL-C; low-density lipoprotein cholesterol; NHANES: National Health and Nutrition Examination Survey; OR: odds ratio; SADHS: South African Demographic and Health Survey; SBP: systolic blood pressure; SHIP: Study of Health in Pomerania; WBC: white blood cell. 
TABLE 2: Studies reporting inflammatory involvement in the interrelationship between hypertension and periodontitis.

\begin{tabular}{|c|c|c|c|c|c|}
\hline Study & Design & $\begin{array}{c}\text { Periodontal } \\
\text { evaluation }\end{array}$ & $\begin{array}{c}\text { Inflammatory } \\
\text { markers }\end{array}$ & $\begin{array}{c}\text { Hypertension-related } \\
\text { parameters }\end{array}$ & Key findings \\
\hline $\begin{array}{l}\text { Higashi et al. } \\
2009[65]\end{array}$ & Prospective & $\begin{array}{l}\text { PPD } \\
\text { CAL } \\
\text { GB }\end{array}$ & $\begin{array}{l}\text { CRP } \\
\text { IL-6 }\end{array}$ & $\begin{array}{l}\text { Forearm blood } \\
\text { flow responses } \\
\text { to vasoactive } \\
\text { substances, } \\
\text { SBP and } \\
\text { DBP } \\
\end{array}$ & $\begin{array}{l}\text { Periodontitis is associated } \\
\text { with reduced NO } \\
\text { bioavailability and ED, with } \\
\text { systemic inflammation as a } \\
\text { predictor of ED }\end{array}$ \\
\hline $\begin{array}{l}\text { Papapanagiotou } \\
\text { et al. } 2009[66]\end{array}$ & Case-control & $\begin{array}{c}\text { Reported } \\
\text { periodontitis }\end{array}$ & $\begin{array}{c}\text { Leukocyte } \\
\text { counts } \\
\text { Platelet count } \\
\text { CRP } \\
\text { P-selectin } \\
\end{array}$ & SBP and DBP & $\begin{array}{l}\text { Periodontitis is associated } \\
\text { with platelet activation }\end{array}$ \\
\hline $\begin{array}{l}\text { Herrera et al. } \\
2011 \text { [67] }\end{array}$ & Experimental & $\begin{array}{l}\text { X-ray bone loss } \\
\text { assessment }\end{array}$ & $\begin{array}{l}\text { MPO } \\
\text { TBARS } \\
\text { NT } \\
\end{array}$ & $\mathrm{NO}$ & $\begin{array}{l}\text { NO contributes to the } \\
\text { systemic effects of } \\
\text { periodontitis }\end{array}$ \\
\hline $\begin{array}{l}\text { Eder et al. } 2012 \\
{[68]}\end{array}$ & Case-control & $\begin{array}{l}\text { Radiography } \\
\text { (WHO) }\end{array}$ & $\begin{array}{l}\mathrm{PGE}_{2} \\
\mathrm{TXB}_{2}\end{array}$ & $\mathrm{PGI}_{2}$ & $\begin{array}{l}\text { Presence of granuloma in } \\
\text { periodontitis is linked to } \\
\text { inflammation and the } \\
\text { synthesis of metabolites of } \\
\text { AA }\end{array}$ \\
\hline $\begin{array}{l}\text { Brito et al. } 2013 \\
{[69]}\end{array}$ & Experimental & $\begin{array}{l}\text { Measurement of } \\
\text { alveolar bone } \\
\text { loss of } \\
\text { mandibles }\end{array}$ & $\begin{array}{l}\text { Leukocyte } \\
\text { counts } \\
\text { IL-6 } \\
\text { CRP }\end{array}$ & $\begin{array}{c}\text { Mean arterial } \\
\text { pressure, } \\
\text { vascular reactivity }\end{array}$ & $\begin{array}{c}\text { Periodontitis induces } \\
\text { systemic and vascular } \\
\text { inflammation which lead to } \\
\text { ED }\end{array}$ \\
\hline
\end{tabular}

AA: arachidonic acid; CAL: clinical attachment loss; CRP: C-reactive protein; DBP: diastolic blood pressure; ED: endothelial dysfunction; GB: gingival bleeding; IL: interleukin; MPO: myeloperoxidase; NO: nitric oxide; NT: nitrotyrosine-containing protein; $\mathrm{PGE}_{2}$ : prostaglandin $\mathrm{E}_{2}$; $\mathrm{PGI}_{2}$ : prostacyclin; $\mathrm{PPD}$ : probing pocket depth; SBP: systolic blood pressure; TBARS: thiobarbituric acid reactive substances; $\mathrm{TXB}_{2}$ : thromboxane $\mathrm{B}_{2}$; WHO: World Health Organisation.

been proposed as an important factor that may exert adverse effects on the regulation of BP (Table 2). The level of serum high-sensitivity CRP (hs-CRP), an acute-phase reactant that has been reported to predict the outcome of CVD, was found to be more increasing in patients with periodontitis than in control subjects, and it decreased significantly after periodontal treatment [73-75].

The association of CRP with hypertension in the setting of periodontitis has not been consistent, possibly due to many other factors that can elevate inflammatory markers, or simply hypertension itself is a multifactorial disease. However, it has recently been proposed that hs-CRP may be a useful marker linking periodontal disease and chronic inflammation [76] which leads to endothelial dysfunction [69]. Periodontitis has been reported to attenuate endotheliumdependent vasodilatation in experimental rats. This ill-effect was due to the elevation of systemic inflammatory biomarkers (CRP and IL-6), worsening the lipid profile, and increased production of vascular superoxide radicals and reduction of vascular nitric oxide synthase-3 (NOS-3) expression [69]. Furthermore, periodontitis is not confined to a localized lesion but may contribute to an increased systemic immune response in patients [77]. Periodontitis may therefore be capable to induce vascular inflammation which leads to endothelial dysfunction, an initial step for CVD. Al-Ghurabei [78] has documented that serum levels of hs-CRP and IL-6 were significantly elevated in patients with chronic periodontitis as compared to healthy control group. On the other hand, Vidal et al. [79] demonstrated that periodontal treatment reduces IL-6, CRP, and fibrinogen levels in patients having hypertension and severe periodontitis. Thus, it is getting clearer that inflammation might provide a potential link between hypertension and periodontitis.

4.2. Oral Infection. Periodontal bacterial infection may also be involved, at least in part, in the development of hypertension. Periodontitis results from the accumulation of bacterial species in subgingival biofilm, particularly by Gram-negative anaerobic and microaerophilic bacteria, such as $P$. gingivalis, Prevotella intermedia, Prevotella nigrescens, Tannerella forsythia, Treponema denticola, Fusobacterium nucleatum, Aggregatibacter actinomycetemcomitans, and Campylobacter rectus [33-35]. These periodontal pathogens are able to destruct and invade gingival tissues by proteolysis then enter the systemic circulation, causing transient bacteraemia [36]. Subsequently, the periodontal microbes may directly invade the arterial wall and lead to vascular inflammation and atherosclerosis [36].

Marcelino et al. [80] reported that $P$. gingivalis is the most prevalent bacterium harboured in atheromas, with its presence found in $50 \%$ of the atheroma samples obtained from patients with periodontitis. Infection of macrophages with $P$. gingivalis itself, and its outer membrane vesicles, is able to induce higher levels of foam cell formation [81]. P. gingivalis and its vesicles not only promote low-density lipoprotein 
(LDL) binding to macrophages but also induce macrophages to modify native LDL, which plays an important role in foam cell formation and the pathogenesis of atherosclerosis [81]. The wild-type strain has been shown to adhere to and enter human macrophages, suggesting the ability of $P$. gingivalis to invade macrophages may play an important role in its atherogenic potential [82].

Moreover, $P$. gingivalis has been demonstrated to induce the expression of cell adhesion molecules including ICAM1, VCAM-1, P-selectin, and E-selectin [83]. P. gingivalis is reported to cause activation of endothelial cells and platelets which are the hallmark of atherogenesis [84]. Activation of endothelial cells is also involved in the pathogenesis of hypertension. Therefore, periodontopathogens from periodontal lesions into the circulation may deliver virulent factors to the arterial wall to initiate and/or promote foam cell formation in macrophages, thus contributing to development of CVD.

4.3. Oxidative Stress. Reactive oxygen species (ROS) such as superoxide anions and hydrogen peroxides are chemically reactive molecules. They damage cellular components including lipid membranes, nucleic acids, and proteins. ROS are formed as natural by-products during physiological processes in cell membranes, mitochondria, and endoplasmic reticulum. In addition, ROS can be generated from tobacco, pollutants, drugs, and ionizing radiation. However, excessive production of ROS leads to oxidative stress with an increase in the formation of free radicals as well as a decrease in antioxidant levels.

There is a growing evidence which indicates that periodontitis induces excessive production of ROS in periodontal tissue [85-90]. Therefore, oxidative stress is suggested to be involved in the pathogenesis of periodontal tissue destruction. Clinical studies have reported that periodontitis is correlated with increased lipid peroxidation in saliva and gingival crevicular fluid $[85,87,89]$. In addition, experimental studies revealed that oxidative damage on periodontal tissue was due to periodontitis [86] along with an elevation of hydrogen peroxide in polymorphonuclear leukocytes [90].

As the condition of periodontitis worsens, the production of ROS increases in response to periodontal inflammation; subsequently ROS enter the systemic circulation [91, 92]. With such, oxidation of biomolecules leads to circulating oxidative stress, which may damage various organs. Hence, the increase in circulating oxidative stress elicited by periodontitis may cause detrimental effects on systemic health.

Oxidative stress induced by locally infiltrating immune cells also participates in hypertension. Oxidative stress has been implicated in the development of hypertension. ROS are widely accepted as the mediators for vasoconstriction and vascular inflammation, and bioavailability of NO is strongly related to hypertension $[93,94]$. Reactive oxygen radicals produced from the destruction of periodontal tissue cause an imbalance between oxidant and antioxidant activities. Furthermore, bacterial endotoxins such as lipopolysaccharides may promote oxidative stress mediated by mitochondrial dysfunction that lowers coenzyme $\mathrm{Q}_{10}$ level and citrate synthase activity, which further increase the rate of free radical production [95].
Imbalance between oxidant and antioxidant activities within the oral cavity negatively affects systemic oxidant status, as reflected by reduced antioxidant capacity [96]. D’Aiuto et al. [97] demonstrated that patients with periodontitis had higher diacron-reactive oxygen metabolites (D-ROM) and lower total antioxidant scavengers compared to healthy controls. The findings were independent of matching age and gender, as well as other confounders including ethnicity, smoking, and standard lipid profiles [97].

4.4. Endothelial Dysfunction. NO is released by the endothelium in order to regulate homeostasis of vascular system. High BP has been suggested to be associated with the imbalance between antioxidant and ROS production [98100]. The impairment of endothelium-dependent relaxation is observed in hypertensive subjects and experimental models [101-106]. This occurrence may be due to a reduction in NO bioavailability, either via a decrease in production or an increased deactivation by ROS in the vascular wall. Peroxynitrite, a cytotoxic prooxidant resultant from the reaction between NO and ROS, is able to compromise endothelial integrity.

Periodontal disease may contribute to endothelial dysfunction [107], which eventually increases the risk of hypertension. NO deficiency is strongly related to the redox imbalance [108]. Inducible nitric oxide synthase (iNOS), which is expressed exclusively under inflammatory condition to produce large amounts of prooxidative $\mathrm{NO}$, is prominently expressed in gingival tissues with periodontitis [109]. Furthermore, given that inflammation or even oxidative stress can destruct extracellular matrix (ECM) [110, 111], it is possible that periodontitis may link to adverse vascular remodelling. Damage to the ECM has been shown to cause structural and functional alterations, consequently affecting cell adhesion, proliferation, and signalling pathway. Hence, this impairment of elastic properties of large arteries plays a significant part in the development and progression of hypertension.

Various studies documented the involvement of endothelial dysfunction in periodontitis with the presence of inflammatory biomarkers. Seinost et al. [112] showed that flowmediated dilation was lower in patients with periodontitis than in the control in addition to an elevation in CRP concentration. Higashi et al. [65] reported that periodontal therapy reduced serum concentrations of CRP and IL- 6 and enhanced acetylcholine-induced vasodilatation in patients with periodontitis. Severe periodontitis is associated with significant endothelial dysfunction that is reversible after successful periodontal therapy in hypertensive patients [113]. Elter et al. [114] also demonstrated that periodontal treatment significantly improved endothelial function, serum CRP, and IL-6 levels.

\section{Conclusion}

In summary, the current epidemiological data, mainly from cross-sectional studies, show an association between hypertension and periodontitis. However, there is no strong proof to indicate that a causal relationship exists. In order to connect the relationships between dentistry and medicine, 
additional issue needs to be addressed for the improvement in managing the overall health of patients. Future studies should be conducted to yield better understanding of the mechanisms and interactions between hypertension and periodontitis, which will further strengthen the involvement between dental and medical communities. Since previous studies demonstrated an elevation in BP which is associated with periodontitis, preventive approaches targeted at reducing BP should also be included in the management of periodontitis. Periodontal health is achievable in both individual level as well as the population level. These preventive measures should be emphasized in oral health promotion programme, in order to enhance overall health outcomes.

\section{Conflict of Interests}

The authors declare that there is no conflict of interests regarding the publication of this paper.

\section{References}

[1] L. J. Jin, G. K. C. Chiu, and E. F. Corbet, "Are periodontal diseases risk factors for certain systemic disorders-what matters to medical practitioners?” Hong Kong Medical Journal, vol. 9, no. 1, pp. 31-37, 2003.

[2] M. S. Tonetti and T. E. Van Dyke, "Periodontitis and atherosclerotic cardiovascular disease: consensus report of the Joint EFP/AAP Workshop on Periodontitis and Systemic Diseases," Journal of Periodontology, vol. 84, no. 4, supplement, pp. S24S29, 2013.

[3] K. S. Kornman, R. C. Page, and M. S. Tonetti, “The host response to the microbial challenge in periodontitis: assembling the players," Periodontology 2000, vol. 1997, no. 14, pp. 33-53, 1997.

[4] B. Noack, R. J. Genco, M. Trevisan, S. Grossi, J. J. Zambon, and E. De Nardin, "Periodontal infections contribute to elevated systemic C-reactive protien level," Journal of Periodontology, vol. 72, no. 9, pp. 1221-1227, 2001.

[5] S. Anil and H. S. Al-Ghamdi, "The impact of periodontal infections on systemic diseases. An update for medical practitioners," Saudi Medical Journal, vol. 27, no. 6, pp. 767-776, 2006.

[6] M. A. Fisher, W. S. Borgnakke, and G. W. Taylor, "Periodontal disease as a risk marker in coronary heart disease and chronic kidney disease," Current Opinion in Nephrology and Hypertension, vol. 19, no. 6, pp. 519-526, 2010.

[7] L. L. Humphrey, R. Fu, D. I. Buckley, M. Freeman, and M. Helfand, "Periodontal disease and coronary heart disease incidence: a systematic review and meta-analysis," Journal of General Internal Medicine, vol. 23, no. 12, pp. 2079-2086, 2008.

[8] M. Zamirian, S. Raoofi, H. Khosropanah, and R. Javanmardi, "Relationship between periodontal disease and acute myocardial infection," Iranian Cardiovasular Research Journal, vol. 1, no. 4, pp. 216-221, 2008.

[9] P. B. Lockhart, A. F. Bolger, P. N. Papapanou et al., "Periodontal disease and atherosclerotic vascular disease: does the evidence support an independent association? A scientific statement from the american heart association," Circulation, vol. 125, no. 20, pp. 2520-2544, 2012.

[10] American Academy of Periodontology, "Periodontal disease linked to cardiovascular disease," April 2012, http://www .perio.org/consumer/AHA-statement.
[11] C. Savoia and E. L. Schiffrin, "Inflammation in hypertension," Current Opinion in Nephrology and Hypertension, vol. 15, no. 2, pp. 152-158, 2006.

[12] D. G. Harrison, A. Vinh, H. Lob, and M. S. Madhur, "Role of the adaptive immune system in hypertension," Current Opinion in Pharmacology, vol. 10, no. 2, pp. 203-207, 2010.

[13] E. L. Schiffrin, "The immune system: role in hypertension," Canadian Journal of Cardiology, vol. 29, no. 5, pp. 543-548, 2013.

[14] A. A. Khraibi, R. A. Norman Jr., and D. J. Dzielak, "Chronic immunosuppression attenuates hypertension in Okamoto spontaneously hypertensive rats," American Journal of Physiology-Heart and Circulatory Physiology, vol. 16, no. 5, pp. H722-H726, 1984.

[15] R. A. Norman Jr., D. J. Dzielak, K. L. Bost, A. A. Khraibi, and P. G. Galloway, "Immune system dysfunction contributes to the aetiology of spontaneous hypertension," Journal of Hypertension, vol. 3, no. 3, pp. 261-268, 1985.

[16] R. A. Norman Jr. and D. J. Dzielak, "Spontaneous hypertension is primarily the result of sympathetic overactivity and immunologic dysfunction," Proceedings of the Society for Experimental Biology and Medicine, vol. 182, no. 4, pp. 448-453, 1986.

[17] D. J. Dzielak, “The immune system and hypertension," Hypertension, vol. 19, no. 1, pp. I36-I44, 1992.

[18] J. T. Parissis, S. Korovesis, E. Giazitzoglou, P. Kalivas, and D. Katritsis, "Plasma profiles of peripheral monocyte-related inflammatory markers in patients with arterial hypertension. Correlations with plasma endothelin-1," International Journal of Cardiology, vol. 83, no. 1, pp. 13-21, 2002.

[19] P. Kampus, P. Muda, J. Kals et al., “The relationship between inflammation and arterial stiffness in patients with essential hypertension," International Journal of Cardiology, vol. 112, no. 1, pp. 46-51, 2006.

[20] H. A. R. Da Fonseca, F. A. H. Fonseca, A. M. Monteiro et al., "Inflammatory environment and immune responses to oxidized LDL are linked to systolic and diastolic blood pressure levels in hypertensive subjects," International Journal of Cardiology, vol. 157, no. 1, pp. 131-133, 2012.

[21] Y. M. Kim, M. Y. Kim, H. J. Kim et al., "Compound C independent of AMPK inhibits ICAM-1 and VCAM-1 expression in inflammatory stimulants-activated endothelial cells in vitro and in vivo," Atherosclerosis, vol. 219, no. 1, pp. 57-64, 2011.

[22] T. Chiba and O. Ezaki, "Dietary restriction suppresses inflammation and delays the onset of stroke in stroke-prone spontaneously hypertensive rats," Biochemical and Biophysical Research Communications, vol. 399, no. 1, pp. 98-103, 2010.

[23] J. Constans and C. Conri, "Circulating markers of endothelial function in cardiovascular disease," Clinica Chimica Acta, vol. 368, no. 1-2, pp. 33-47, 2006.

[24] A. S. Postadzhiyan, A. V. Tzontcheva, I. Kehayov, and B. Finkov, "Circulating soluble adhesion molecules ICAM-1 and VCAM1 and their association with clinical outcome, troponin $\mathrm{T}$ and C-reactive protein in patients with acute coronary syndromes," Clinical Biochemistry, vol. 41, no. 3, pp. 126-133, 2008.

[25] C. Y. Ng, Y. Kamisah, O. Faizah, and K. Jaarin, "The role of repeatedly heated soybean oil in the development of hypertension in rats: association with vascular inflammation," International Journal of Experimental Pathology, vol. 93, no. 5, pp. 377387, 2012.

[26] P. M. Kearney, M. Whelton, K. Reynolds, P. Muntner, P. K. Whelton, and J. He, "Global burden of hypertension: analysis of worldwide data," Lancet, vol. 365, no. 9455, pp. 217-223, 2005. 
[27] G. L. Khor, "Cardiovascular epidemiology in the Asia-Pacific region," Asia Pacific Journal of Clinical Nutrition, vol. 10, no. 2, pp. 76-80, 2001.

[28] H. H. Vorster, "The emergence of cardiovascular disease during urbanisation of Africans," Public Health Nutrition, vol. 5, no. 1, pp. 239-243, 2002.

[29] A. V. Chobanian, G. L. Bakris, H. R. Black et al., "The seventh report of the joint National Committee on Prevention, detection, evaluation, and treatment of high blood pressure: the JNC 7 report," Journal of the American Medical Association, vol. 289, no. 19, pp. 2560-2572, 2003.

[30] B. J. Paster, S. K. Boches, J. L. Galvin et al., "Bacterial diversity in human subgingival plaque," Journal of Bacteriology, vol. 183, no. 12, pp. 3770-3783, 2001.

[31] B. J. Paster, I. Olsen, J. A. Aas, and F. E. Dewhirst, "The breadth of bacterial diversity in the human periodontal pocket and other oral sites," Periodontology 2000, vol. 42, no. 1, pp. 80-87, 2006.

[32] M. Sanz and A. J. Van Winkelhoff, "Periodontal infections: understanding the complexity-consensus of the Seventh European Workshop on Periodontology," Journal of Clinical Periodontology, vol. 38, no. 11, pp. 3-6, 2011.

[33] P. N. Papapanou, V. Baelum, W.-M. Luan et al., "Subgingival microbiota in adult Chinese: prevalence and relation to periodontal disease progression," Journal of Periodontology, vol. 68, no. 7, pp. 651-666, 1997.

[34] S. S. Socransky, C. Smith, and A. D. Haffajee, "Subgingival microbial profiles in refractory periodontal disease," Journal of Clinical Periodontology, vol. 29, no. 3, pp. 260-268, 2002.

[35] L. Sbordone and C. Bortolaia, "Oral microbial biofilms and plaque-related diseases: microbial communities and their role in the shift from oral health to disease," Clinical oral investigations, vol. 7, no. 4, pp. 181-188, 2003.

[36] F. Panagakos and F. Scannapieco, "Periodontal inflammation: from gingivitis to systemic disease?" in Gingival Diseases: Their Aetiology, Prevention and Treatment, F. Panagakos and R. Davies, Eds., pp. 155-168, InTech, 2011.

[37] A. Passoja, I. Puijola, M. Knuuttila et al., "Serum levels of interleukin-10 and tumour necrosis factor- $\alpha$ in chronic periodontitis," Journal of Clinical Periodontology, vol. 37, no. 10, pp. 881-887, 2010.

[38] M. Soory, "Chronic periodontitis as a risk marker for systemic diseases with reference to cardiometabolic disorders: common pathways in their progression," Immunology and Immunogenetics Insights, vol. 2, pp. 7-21, 2010.

[39] P. Bullon, J. M. Morillo, M. C. Ramirez-Tortosa, J. L. Quiles, H. N. Newman, and M. Battino, "Metabolic syndrome and periodontitis: is oxidative stress a common link?" Journal of Dental Research, vol. 88, no. 6, pp. 503-518, 2009.

[40] K. Wakai, T. Kawamura, O. Umemura et al., "Associations of medical status and physical fitness with periodontal disease," Journal of Clinical Periodontology, vol. 26, no. 10, pp. 664-672, 1999.

[41] M. Gołebiewska, K. Taraszkiewicz-Sulik, A. Kuklińska, and W. J. Musiał, "Periodontal condition in patients with cardiovascular diseases," Advances in Medical Sciences, vol. 51, pp. 69-72, 2006.

[42] A. Holmlund, G. Holm, and L. Lind, "Severity of periodontal disease and number of remaining teeth are related to the prevalence of Myocardial infarction and hypertension in a study based on 4,254 subjects," Journal of Periodontology, vol. 77, no. 7, pp. 1173-1178, 2006.
[43] S. Engström, L. Gahnberg, H. Högberg, and K. Svärdsudd, "Association between high blood pressure and deep periodontal pockets: a nested case-referent study," Upsula Journal of Medical Science, vol. 112, no. 1, pp. 95-103, 2007.

[44] C. Tsioufis, A. Kasiakogias, C. Thomopoulos, and C. Stefanadis, "Periodontitis and blood pressure: the concept of dental hypertension," Atherosclerosis, vol. 219, no. 1, pp. 1-9, 2011.

[45] Y. Ogawa, M. Imaki, Y. Yoshida, M. Matsumoto, and S. Tanada, "Epidemiological study on the relationship between hypertension and dental disease in Japanese factory workers," Sangyo Eiseigaku Zasshi, vol. 40, no. 6, pp. 235-240, 1998.

[46] F. Angeli, P. Verdecchia, C. Pellegrino et al., "Association between periodontal disease and left ventricle mass in essential hypertension," Hypertension, vol. 41, no. 3, pp. 488-492, 2003.

[47] A. Taguchi, M. Sanada, Y. Suei et al., "Tooth loss is associated with an increased risk of hypertension in postmenopausal women," Hypertension, vol. 43, no. 6, pp. 1297-1300, 2004.

[48] K. Inoue, Y. Kobayashi, H. Hanamura, and S. Toyokawa, "Association of periodontitis with increased white blood cell count and blood pressure," Blood Pressure, vol. 14, no. 1, pp. 53$58,2005$.

[49] F. D’Aiuto, M. Parkar, L. Nibali, J. Suvan, J. Lessem, and M. S. Tonetti, "Periodontal infections cause changes in traditional and novel cardiovascular risk factors: results from a randomized controlled clinical trial," American Heart Journal, vol. 151, no. 5, pp. 977-984, 2006.

[50] H. Völzke, C. Schwahn, M. Dörr et al., "Gender differences in the relation between number of teeth and systolic blood pressure," Journal of Hypertension, vol. 24, no. 7, pp. 1257-1263, 2006.

[51] H. Völzke, C. Schwahn, M. Dörr et al., "Inverse association between number of teeth and left ventricular mass in women," Journal of Hypertension, vol. 25, no. 10, pp. 2035-2043, 2007.

[52] O. A. Ayo-Yusuf and I. J. Ayo-Yusuf, "Association of tooth loss with hypertension," South African Medical Journal, vol. 98, no. 5, pp. 381-385, 2008.

[53] E. Franek, E. Klamczynska, E. Ganowicz, A. Blach, T. Budlewski, and R. Gorska, "Association of chronic periodontitis with left ventricular mass and central blood pressure in treated patients with essential hypertension," American Journal of Hypertension, vol. 22, no. 2, pp. 203-207, 2009.

[54] M. Fujita, K. Ueno, and A. Hata, "Lower frequency of daily teeth brushing is related to high prevalence of cardiovascular risk factors," Experimental Biology and Medicine, vol. 234, no. 4, pp. 387-394, 2009.

[55] W. Nesse, P. U. Dijkstra, F. Abbas et al., "Increased prevalence of cardiovascular and autoimmune diseases in periodontitis patients: a cross-sectional study," Journal of Periodontology, vol. 81, no. 11, pp. 1622-1628, 2010.

[56] C. de Oliveira, R. Watt, and M. Hamer, "Toothbrushing, inflammation, and risk of cardiovascular disease: results from Scottish Health Survey," British Medical Journal, vol. 340, article c2451, 2010.

[57] T. Morita, Y. Yamazaki, A. Mita et al., "A cohort study on the association between periodontal disease and the development of metabolic syndrome," Journal of Periodontology, vol. 81, no. 4, pp. 512-519, 2010.

[58] E. Franek, M. Napora, A. Blach et al., "Blood pressure and left ventricular mass in subjects with type 2 diabetes and gingivitis or chronic periodontitis," Journal of Clinical Periodontology, vol. 37, no. 10, pp. 875-880, 2010. 
[59] G. Tsakos, W. Sabbah, A. D. Hingorani et al., "Is periodontal inflammation associated with raised blood pressure? Evidence from a National US survey," Journal of Hypertension, vol. 28, no. 12, pp. 2386-2393, 2010.

[60] M. Desvarieux, R. T. Demmer, D. R. Jacobs Jr. et al., "Periodontal bacteria and hypertension: the oral infections and vascular disease epidemiology study (INVEST)," Journal of Hypertension, vol. 28, no. 7, pp. 1413-1421, 2010.

[61] L. Zhang, Y. F. Li, Z. Z. Liang et al., "The association between chronic periodontitis and hypertension in rural adult Uygur residents," Zhonghua Xin Xue Guan Bing Za Zhi, vol. 39, no. 12, pp. 1140-1144, 2011.

[62] F. Vidal, C. M. S. Figueredo, I. Cordovil, and R. G. Fischer, "Higher prevalence of periodontitis in patients with refractory arterial hypertension: a case-control study," Oral Diseases, vol. 17, no. 6, pp. 560-563, 2011.

[63] M. A. Peres, G. Tsakos, P. R. Barbato, D. A. S. Silva, and K. G. Peres, "Tooth loss is associated with increased blood pressure in adults: a multidisciplinary population-based study," Journal of Clinical Periodontology, vol. 39, no. 9, pp. 824-833, 2012.

[64] S. Rivas-Tumanyan, M. Campos, J. C. Zevallos, and K. J. Joshipura, "Periodontal disease, hypertension and blood pressure among older adults in Puerto Rico," Journal of Periodontology, vol. 84, no. 2, pp. 203-211, 2013.

[65] Y. Higashi, C. Goto, T. Hidaka et al., "Oral infectioninflammatory pathway, periodontitis, is a risk factor for endothelial dysfunction in patients with coronary artery disease," Atherosclerosis, vol. 206, no. 2, pp. 604-610, 2009.

[66] D. Papapanagiotou, E. A. Nicu, S. Bizzarro et al., "Periodontitis is associated with platelet activation," Atherosclerosis, vol. 202, no. 2, pp. 605-611, 2009.

[67] B. S. Herrera, R. Martins-Porto, P. Campi et al., "Local and cardiorenal effects of periodontitis in nitric oxide-deficient hypertensive rats," Archives of Oral Biology, vol. 56, no. 1, pp. 41-47, 2011.

[68] A. Eder, E. Koegl, S. P. von Duvillard, H. Sinzinger, and R. Beret, "Influence of cigarette smoking on synthesis of eicosanoids, isoprostanes and lipoxygenase metabolites in apical periodontitis," Archives of Oral Biology, vol. 57, no. 8, pp. 1133-1140, 2012.

[69] L. C. Brito, S. Dalbó, T. M. Striechen et al., "Experimental periodontitis promotes transient vascular inflammation and endothelial dysfunction," Archives of Oral Biology, vol. 58, no. 9, pp. 1187-1198, 2013.

[70] J. Slowik, M. A. Wnuk, K. Grzech et al., "Periodontitis affects neurological deficit in acute stroke," Journal of the Neurological Sciences, vol. 297, no. 1-2, pp. 82-84, 2010.

[71] J. Shanker, P. Setty, P. Arvind et al., "Relationship between periodontal disease, Porphyromonas gingivalis, peripheral vascular resistance markers and coronary artery disease in Asian Indians," Thrombosis Research, vol. 132, no. 1, pp. e8-e14, 2013.

[72] D. Pasqualini, L. Bergandi, L. Palumbo et al., "Association among oral health, apical periodontitis, CD14 polymorphisms, and coronary heart disease in middle-aged adults," Journal of Endodontics, vol. 38, no. 12, pp. 1570-1577, 2012.

[73] S. Paraskevas, J. D. Huizinga, and B. G. Loos, "A systematic review and meta-analyses on C-reactive protein in relation to periodontitis," Journal of Clinical Periodontology, vol. 35, no. 4, pp. 277-290, 2008.

[74] A. P. Dasanayake, "C-reactive protein levels are elevated in patients with periodontitis and their CRP levels may go down after periodontal therapy," Journal of Evidence-Based Dental Practice, vol. 9, no. 1, pp. 21-22, 2009.
[75] H. Miyashita, T. Honda, T. Maekawa et al., "Relationship between serum antibody titres to Porphyromonas gingivalis and hs-CRP levels as inflammatory markers of periodontitis," Archives of Oral Biology, vol. 57, no. 6, pp. 820-829, 2012.

[76] A. R. Pradeep, M. Kumari, N. Kalra, and N. Priyanka, "Correlation of MCP- 4 and high-sensitivity C-reactive protein as a marker of inflammation in obesity and chronic periodontitis," Cytokine, vol. 61, no. 3, pp. 772-777, 2013.

[77] M. S. Gomes, T. C. Blattner, M. S. Filho et al., "Can apical periodontitis modify systemic levels of inflammatory markers? A systematic review and meta-analysis," Journal of Endodontics, vol. 39, no. 10, pp. 1205-1217, 2013.

[78] B. H. Al-Ghurabei, "Evaluation of serum anti-cardiolipin antibody, hs-CRP and IL-6 levels in chronic periodontitis as possible risk factors for cardiovascular diseases," Journal of Baghdad College of Dentistry, vol. 24, no. 2, pp. 161-165, 2012.

[79] F. Vidal, C. M. S. Figueredo, I. Cordovil, and R. G. Fischer, "Periodontal therapy reduces plasma levels of interleukin6 , c-reactive protein, and fibrinogen in patients with severe periodontitis and refractory arterial hypertension," Journal of Periodontology, vol. 80, no. 5, pp. 786-791, 2009.

[80] S. L. Marcelino, E. Gaetti-Jardim, V. Nakano et al., "Presence of periodontopathic bacteria in coronary arteries from patients with chronic periodontitis," Anaerobe, vol. 16, no. 6, pp. 629632, 2010.

[81] M. Qi, H. Miyakawa, and H. K. Kuramitsu, "Porphyromonas gingivalis induces murine macrophage foam cell formation," Microbial Pathogenesis, vol. 35, no. 6, pp. 259-267, 2003.

[82] M. B. Giacona, P. N. Papapanou, I. B. Lamster et al., "Porphyromonas gingivalis induces its uptake by human macrophages and promotes foam cell formation in vitro," FEMS Microbiology Letters, vol. 241, no. 1, pp. 95-101, 2004.

[83] G. A. Roth, B. Moser, F. Roth-Walter et al., "Infection with a periodontal pathogen increases mononuclear cell adhesion to human aortic endothelial cells," Atherosclerosis, vol. 190, no. 2, pp. 271-281, 2007.

[84] A. Assinger, E. Buchberger, M. Laky, A. Esfandeyari, C. Brostjan, and I. Volf, "Periodontopathogens induce soluble P-selectin release by endothelial cells and platelets," Thrombosis Research, vol. 127, no. 1, pp. e20-e26, 2011.

[85] C. C. Tsai, H. S. Chen, S. L. Chen et al., "Lipid peroxidation: a possible role in the induction and progression of chronic periodontitis," Journal of Periodontal Research, vol. 40, no. 5, pp. 378-384, 2005.

[86] T. Tomofuji, T. Azuma, H. Kusano et al., "Oxidative damage of periodontal tissue in the rat periodontitis model: effects of a high-cholesterol diet," FEBS Letters, vol. 580, no. 15, pp. 36013604, 2006.

[87] F. A. Akalin, E. Baltacioğlu, A. Alver, and E. Karabulut, "Lipid peroxidation levels and total oxidant status in serum, saliva and gingival crevicular fluid in patients with chronic periodontitis," Journal of Clinical Periodontology, vol. 34, no. 7, pp. 558-565, 2007.

[88] I. L. C. Chapple and J. B. Matthews, "The role of reactive oxygen and antioxidant species in periodontal tissue destruction," Periodontology 2000, vol. 43, no. 1, pp. 160-232, 2007.

[89] I. L. C. Chapple, G. R. Brock, M. R. Milward, N. Ling, and J. B. Matthews, "Compromised GCF total antioxidant capacity in periodontitis: cause or effect?" Journal of Clinical Periodontology, vol. 34, no. 2, pp. 103-110, 2007. 
[90] D. Ekuni, T. Tomofuji, N. Tamaki et al., "Mechanical stimulation of gingiva reduces plasma 8-OHdG level in rat periodontitis," Archives of Oral Biology, vol. 53, no. 4, pp. 324-329, 2008.

[91] H. Sobaniec and M. E. Sobaniec-Lotowska, "Morphological examinations of hard tissues of paradontium and evaluation of selected processes of lipid peroxidation in blood serum of rats in the course of experimental periodontitis," Medical Science Monitor, vol. 6, no. 5, pp. 875-881, 2000.

[92] T. Tomofuji, D. Ekuni, R. Yamanaka et al., "Chronic administration of lipopolysaccharide and proteases induces periodontal inflammation and hepatic steatosis in rats," Journal of Periodontology, vol. 78, no. 10, pp. 1999-2006, 2007.

[93] R. M. Touyz, "Reactive oxygen species, vascular oxidative stress, and redox signaling in hypertension: what is the clinical significance?" Hypertension, vol. 44, no. 3, pp. 248-252, 2004.

[94] C. J. Boos and G. Y. H. Lip, "Is hypertension an inflammatory process?" Current Pharmaceutical Design, vol. 12, no. 13, pp. 1623-1635, 2006.

[95] P. Bullon, M. D. Cordero, J. L. Quiles, J. M. Morillo, M. D. C. Ramirez-Tortosa, and M. Battino, "Mitochondrial dysfunction promoted by Porphyromonas gingivalis lipopolysaccharide as a possible link between cardiovascular disease and periodontitis," Free Radical Biology and Medicine, vol. 50, no. 10, pp. 1336-1343, 2011.

[96] G. R. Brock, C. J. Butterworth, J. B. Matthews, and I. L. C. Chapple, "Local and systemic total antioxidant capacity in periodontitis and health," Journal of Clinical Periodontology, vol. 31, no. 7, pp. 515-521, 2004.

[97] F. D’Aiuto, L. Nibali, M. Parkar, K. Patel, J. Suvan, and N. Donos, "Oxidative stress, systemic inflammation, and severe periodontitis," Journal of Dental Research, vol. 89, no. 11, pp. 1241-1246, 2010.

[98] D. Romero-Alvira and E. Roche, "High blood pressure, oxygen radicals and antioxidants: etiological relationships," Medical Hypotheses, vol. 46, no. 4, pp. 414-420, 1996.

[99] M. K. Kashyap, V. Yadav, B. S. Sherawat et al., "Different antioxidants status, total antioxidant power and free radicals in essential hypertension," Molecular and Cellular Biochemistry, vol. 277, no. 1-2, pp. 89-99, 2005.

[100] S. B. Patil, M. V. Kodliwadmath, and S. M. Kodliwadmath, "Correlation between lipid peroxidation and non-enzymatic antioxidants in pregnancy induced hypertension," Indian Journal of Clinical Biochemistry, vol. 23, no. 1, pp. 45-48, 2008.

[101] S. Taddei, A. Virdis, L. Ghiadoni, A. Magagna, and A. Salvetti, "Vitamin C improves endothelium-dependent vasodilation by restoring nitric oxide activity in essential hypertension," Circulation, vol. 97, no. 22, pp. 2222-2229, 1998.

[102] S. Verma and T. J. Anderson, "Fundamentals of endothelial function for the clinical cardiologist," Circulation, vol. 105, no. 5, pp. 546-549, 2002.

[103] R. Rodriguez-Rodriguez, M. D. Herrera, M. A. de Sotomayor, and V. Ruiz-Gutierrez, "Pomace olive oil improves endothelial function in spontaneously hypertensive rats by increasing endothelial nitric oxide synthase expression," American Journal of Hypertension, vol. 20, no. 7, pp. 728-734, 2007.

[104] J.-Z. Xu, Y. Zhang, S.-N. Wu, W.-Q. Niu, D.-L. Zhu, and P.-J. Gao, "Impaired endothelial function in hypertensive patients with target organ damage," Journal of Human Hypertension, vol. 23, no. 11, pp. 751-757, 2009.

[105] X.-F. Leong, M. R. Mustafa, S. Das, and K. Jaarin, "Association of elevated blood pressure and impaired vasorelaxation in experimental Sprague-Dawley rats fed with heated vegetable oil," Lipids in Health and Disease, vol. 9, article 66, 2010.

[106] C. Gray, M. Li, C. M. Reynolds, and M. H. Vickers, "Preweaning growth hormone treatment reverse hypertension and endothelial dysfunction in adult male offspring of mothers undernourished during pregnancy," PLoS One, vol. 8, no. 1, article e53505, 2013.

[107] M. S. Tonetti, F. D’Aiuto, L. Nibali et al., "Treatment of periodontitis and endothelial function," The New England Journal of Medicine, vol. 356, no. 9, pp. 911-920, 2007.

[108] S. L. H. Ong and J. A. Whitworth, "How do glucocorticoids cause hypertension: role of nitric oxide deficiency, oxidative stress, and eicosanoids," Endocrinology and Metabolism Clinics of North America, vol. 40, no. 2, pp. 393-407, 2011.

[109] O. Shaker, N. A. Ghallab, E. Hamdy, and S. Sayed, "Inducible nitric oxide synthase (iNOS) in gingival tissues of chronic periodontitis with and without diabetes: immunohistochemistry and RT-PCR study," Archives of Oral Biology, vol. 58, no. 10, pp. 1397-1406, 2013.

[110] C. Vlachopoulos, I. Dima, K. Aznaouridis et al., "Acute systemic inflammation increases arterial stiffness and decreases wave reflections in healthy individuals," Circulation, vol. 112, no. 14, pp. 2193-2200, 2005.

[111] M. D. Rees, E. C. Kennett, J. M. Whitelock, and M. J. Davies, "Oxidative damage to extracellular matrix and its role in human pathologies," Free Radical Biology and Medicine, vol. 44, no. 12, pp. 1973-2001, 2008.

[112] G. Seinost, G. Wimmer, M. Skerget et al., "Periodontal treatment improves endothelial dysfunction in patients with severe periodontitis," American Heart Journal, vol. 149, no. 6, pp. 10501054, 2005.

[113] F. Vidal, I. Cordovil, C. M. S. Figueredo, and R. G. Fischer, "Non-surgical treatment reduces cardiovascular risk in refractory hypertensive patients: a pilot study," Journal of Clinical Periodontology, vol. 40, no. 7, pp. 681-687, 2013.

[114] J. R. Elter, A. L. Hinderliter, S. Offenbacher et al., "The effects of periodontal therapy on vascular endothelial function: a pilot trial," American Heart Journal, vol. 151, no. 47, pp. el-e6, 2006. 


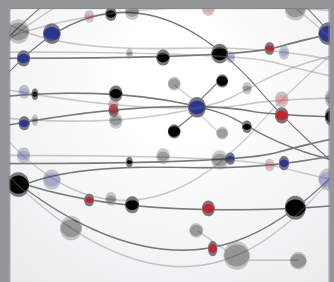

The Scientific World Journal
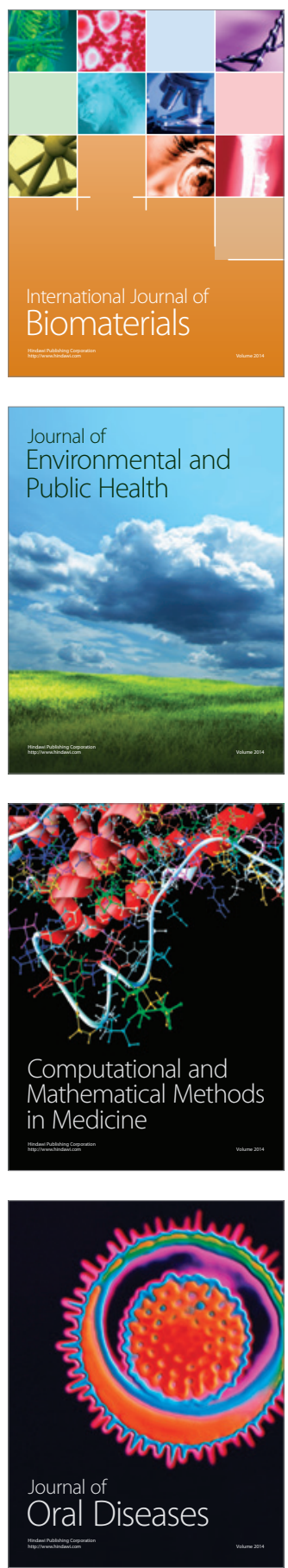
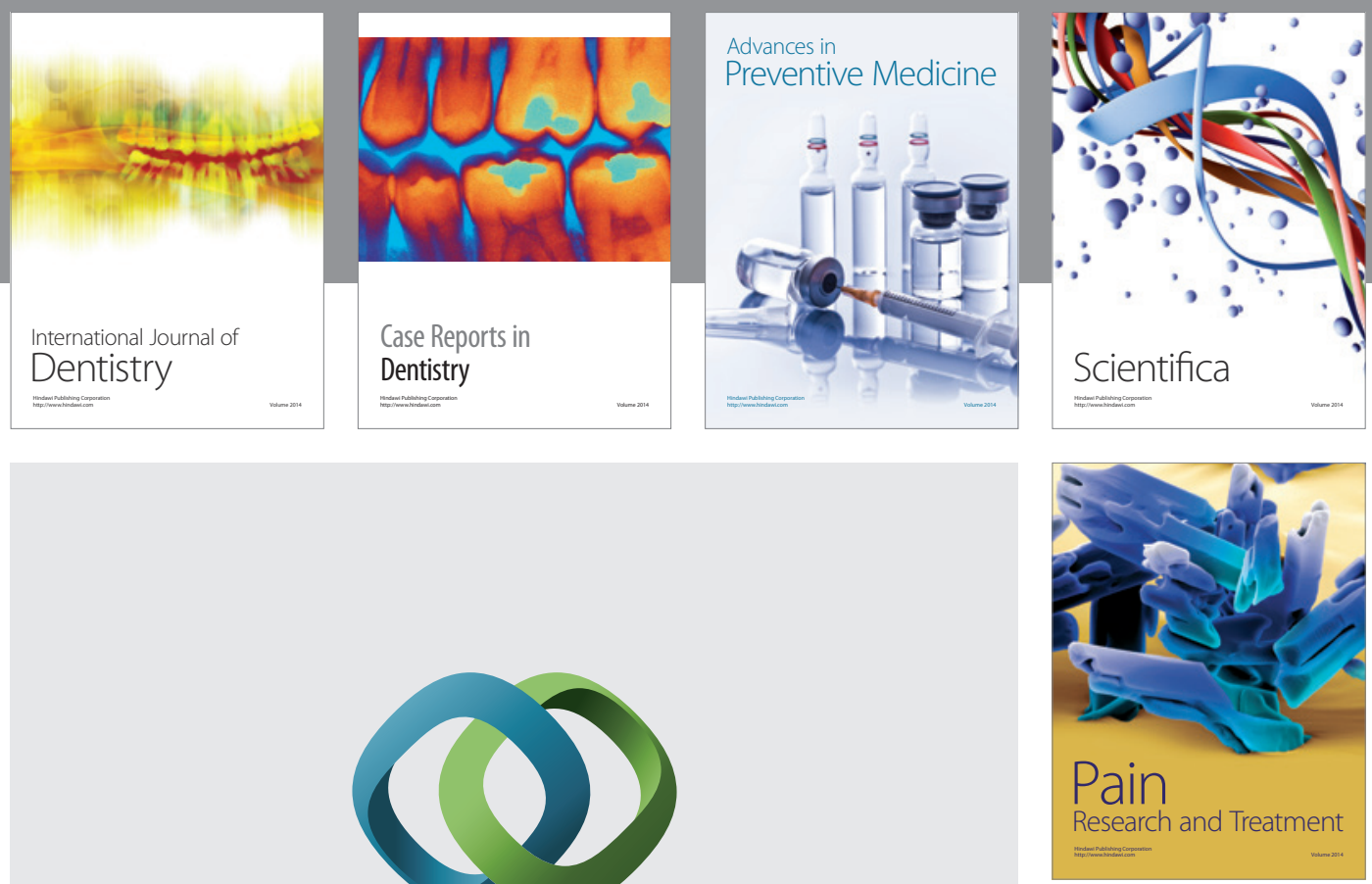

\section{Hindawi}

Submit your manuscripts at

http://www.hindawi.com
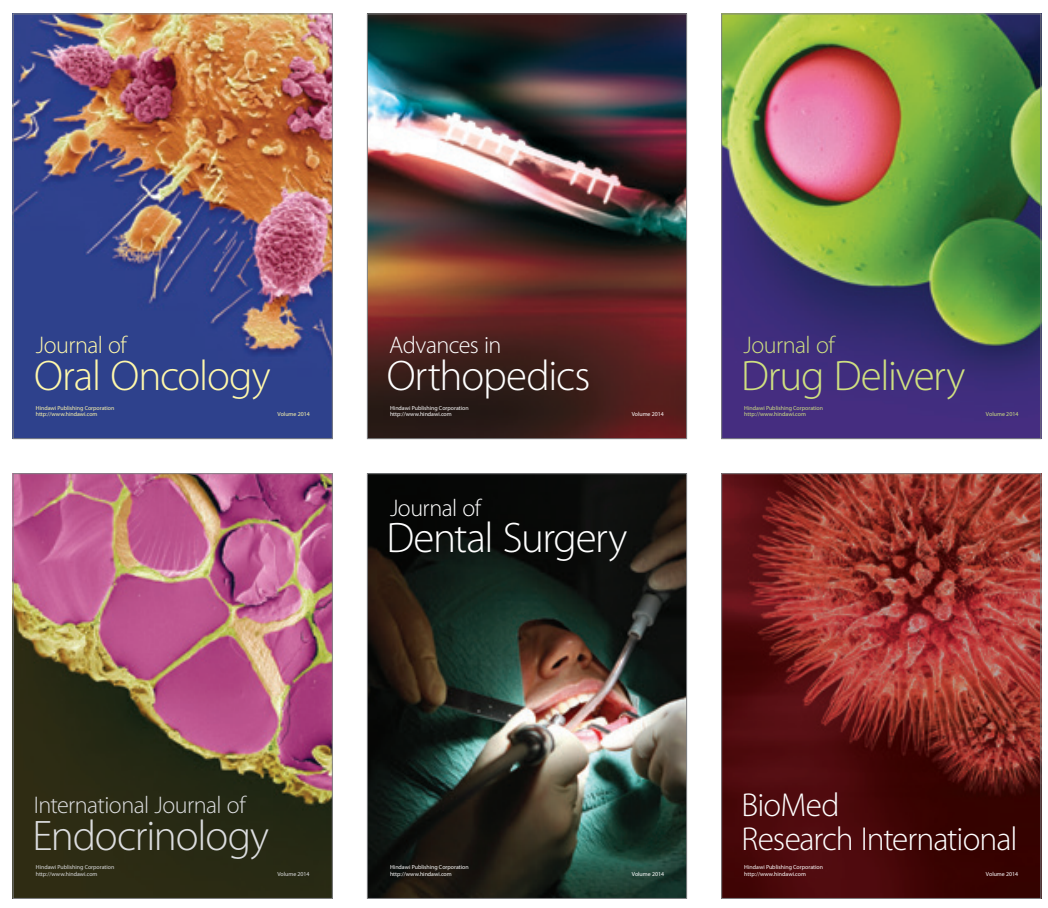

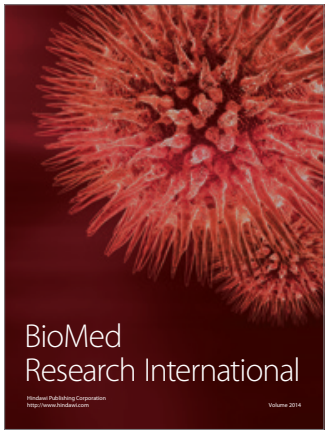

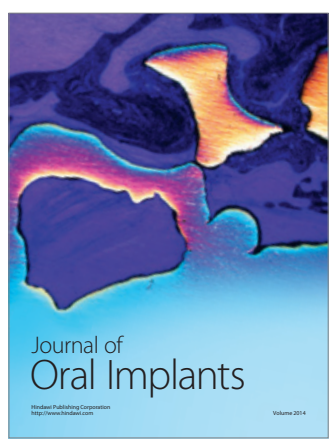
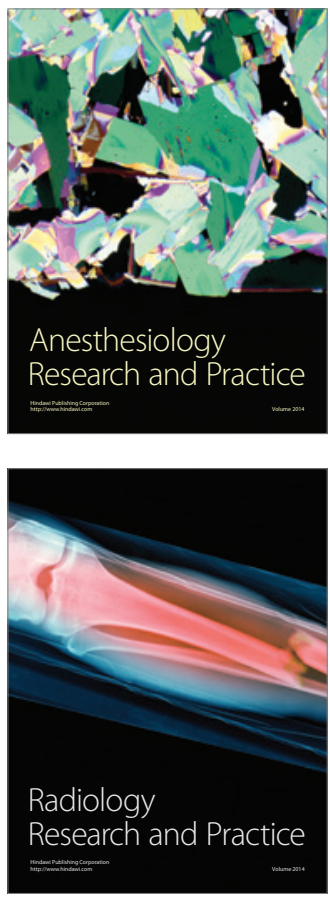